\title{
Conclusion
}

The Labour Government's travails over In Place of Strife and the ensuing Industrial Relations Bill have variously been blamed, by some of those most closely involved, for the Party's defeat in the 1970 general election. Their critiques are outlined below, but given the controversy surrounding the White Paper and associated legislative proposals, it is worth considering why Harold Wilson decided to call the general election in 1970 anyway. At that time, there was no Fixed Term Parliament Act, and hence a Prime Minister was entitled to call a general election at any time within five years of the previous election. Having been re-elected in 1966, the Labour Government could have deferred an election until 1971, by which time, the controversies and bitterness engendered by the proposed, and then abandoned, industrial relations legislation might have abated.

According to Wilson's Press Secretary, Joe Haines, a major reason for not opting to serve the full five-year term was that in early 1971, Britain would be adopting a new currency - 'decimalisation' (BBC, 2011). Some Ministers feared that this might prove so controversial and unpopular (even if only temporarily until people became accustomed to it), that the Government could suffer an electoral backlash. Consequently, a 1970 general election became the default option, the main discussion being over whether it should be held in the early summer (before the schools closed, and many families went away on holiday) or the autumn. Haines acknowledged that '[i]n favour of waiting until the autumn was the fact that the wounds inflicted upon Labour voters between 1967 and 1969 - devaluation, the wage freeze, tax increases, the battle with the unions - would take a little longer to heal' (Haines, 1977: 170).

However, June was chosen for several reasons, one of the most influential being Labour's improved performance in May's local government elections, coupled with a concomitant increase in the Party's support in opinion polls (Wilson, 1971: 778). This naturally buoyed the confidence of many Cabinet Ministers, and seemingly convinced them that the bitterness 
aroused by the previous year's industrial relations proposals had largely dissipated. In fact, Wilson subsequently confessed that he had 'virtually decided', on 13 April 1970, that the general election should be held on 18 June, although he naturally wanted first to analyse the mid-May local election results, to gauge the scale and strength of Labour's electoral recovery, and then consult with senior colleagues, before making a final decision and announcement (Wilson, 1971: 778). In fact, only two senior Ministerial colleagues were consulted by Wilson before he informed the Cabinet of his decision, namely the Chancellor - who had no strong preference concerning the date - and Peter Shore, who definitely favoured June (Haines, 2003: 23-4).

A further factor alluded to by Wilson, when he informed the Cabinet that he was going to call a June election, was international affairs. Indeed, Wilson deemed that:

[o]ne of the most important considerations was the uncertainty of the international prospect in relation to such issues as European security ... and the need for the Government to be able to speak for the United Kingdom with authority in the forthcoming negotiations for entry into the European Communities. ${ }^{1}$

He also referred to the heightened expectations of the electorate regarding a June election. Moreover, Wilson pointed out that if the Government deferred the election, it 'would find it progressively more difficult to control events and would increasingly lose the power of initiative." ${ }^{2}$

This last observation highlighted a perennial dilemma facing governments and Prime Ministers in the era long before the 2011 Fixed Term Parliament Act. If a Government had faced difficulties or/and unpopularity during the third or fourth year in office, the natural temptation was to serve the full five years, in the Micawberish hope that its fortunes would improve in the final year, sufficient to secure re-election. Yet this offered a hostage to fortune by placing the Government at the mercy of unforeseen events, which might perpetuate or even exacerbate its unpopularity, and therefore further damage its electoral prospects at the end of the five-year term.

A further reason cited for choosing June, according to Haines, was that the Conservatives were expecting an autumn election, and were thus planning to pursue a major advertising campaign over the summer: 'A June election would put a stop to that'(Haines, 1977: 170; see also Haines, 2003: 23).

Finally, it was acknowledged that an autumn general election would be conducted in the context of less clement weather, darker evenings and an electoral register which was almost a year out of date (Haines 2003: 23), although such objections did not dissuade Wilson from later calling 
Table 3 Results of the 1970 general election, with corresponding figures for 1966

\begin{tabular}{lccc}
\hline & Votes & Share $(\%)$ & Seats \\
\hline Conservative & $13,145,123(11,418,455)$ & $46.2(41.4)$ & $330(253)$ \\
Labour & $12,208,758(13,096,629)$ & $43.9(48.9)$ & $288(364)$ \\
Liberal & $2,117,035(2,327,457)$ & $7.6(8.6)$ & $6(12)$ \\
Others & $873,882(422,206)$ & $2.3(1.1)$ & $6(1)$ \\
\hline
\end{tabular}

(http://www.bbc.co.uk/news/special/politics97/background/pastelec).

a general election for October 1974, albeit under rather different political circumstances.

The result of the 1970 general election is in Table 3, with the corresponding figures for 1966 in brackets to show the scale of the changes.

What these figures do not show was the proportional decline in turnout between 1966 and 1970, from 75.8 per cent to 72 per cent, although the actual number of people who voted in 1970 was somewhat higher than four years earlier. This apparent discrepancy is explained by the fact that, in 1969, the minimum age of voting had been reduced from 21 to 18 , thereby increasing the total electorate from 36 million people to 39.3 million. However, although more than 3 million new voters had been added to the electoral register only just over 1 million additional votes were cast in 1970, hence the drop in turnout in percentage terms.

\section{Accounts of Labour's defeat}

It was almost inevitable that In Place of Strife, and the subsequent abandonment of the proposed industrial relations legislation, would feature prominently in much of the debate about why Labour lost the 1970 general election, in spite of the strong lead which the Party had enjoyed in several opinion polls during the campaign. However, there emerged two markedly different perspectives about the manner in which In Place of Strife and the Industrial Relations Bill allegedly contributed towards Labour's electoral defeat, these contrasting interpretations depending on whether the commentator had supported or opposed the White Paper and the subsequent proposed legislation.

To the proponents and supporters of In Place of Strife and the subsequent Industrial Relations Bill, it was the failure to enact the intended reform of industrial relations and trade unionism which contributed significantly to Labour's electoral defeat a year later. According to Michael Stewart, 
who had been Foreign Secretary in 1969 and remained supportive of In Place of Strife throughout, even while other senior Minister were withdrawing their support in the face of opposition from the trade unions and much of the PLP, the failure to enact the proposed industrial relations legislation cost Labour electorally. Had the Government persevered, and shown firm leadership, it 'would have made a most favourable impression in the country, and gone a long way towards winning us the approaching Election' (Stewart, 1980: 253).

Meanwhile, the biographer of Chancellor Roy Jenkins claims that the Labour Government's 'ignominious surrender to the unions over In Place of Strife probably contributed more than anything else to Labour's defeat the following year', in the 1970 general election (Campbell, 2014: 346). Similarly, Joe Haines averred that ' $[\mathrm{t}]$ he failure of In Place of Strife indirectly cost Labour the election' (Haines, 2003: 17). This critique held that a growing number of voters, including many trade union members, had become exasperated by the industrial disruption caused by strikes, particularly those of an unconstitutional or unofficial character which were, by definition, unpredictable. Consequently, these voters were deemed to be deeply disappointed at the Labour Government's perceived capitulation to the trade unions in June 1969, and were not remotely convinced that the 'solemn and binding' agreement with the TUC would have any discernible or enduring impact on strikes. In this context, the Conservatives' pledge to enact clear and comprehensive industrial relations legislation, based on Fair Deal at Work, was deemed likely to have persuaded some erstwhile Labour voters to switch to the Conservative Party in the June 1970 general election.

Against this perspective, critics and opponents of In Place of Strife and the Industrial Relations Bill claimed that it was the stubborn pursuit of such legislation during the first half of 1969, rather than its subsequent failure per se, which seriously damaged Labour's electoral performance in 1970. According to this interpretation, Wilson and Castle especially had alienated many erstwhile Labour voters as a consequence of their desire to place statutory obligations and restrictions on the trade unions and their members, especially after several years of enforced wage restraint via a succession of incomes policies. The Labour Government had seemingly been pre-occupied with curbing workers' pay and collective bargaining, and cutting the social wage, in order to impress the City and international financiers with its economic and fiscal probity; no corresponding curbs were placed on the business community or boardroom pay.

For example, when Wilson opted for a June 1970 election, even though constitutionally he could have waited another year, Joe Gormley warned him that it was too soon, because ' $[t]$ he scars of your industrial relations policy haven't healed yet ... You've soured your supporters .... You've hurt that trade union support.' Not only was this likely to reduce Labour's support 
on polling day, Gormley explained, it also meant that during the election campaign itself the Party would struggle to muster sufficient activists to mobilise support: 'In Lancashire ... where I used to be able to get three or four hundred miners out on to the streets and the hustings - well, I'd be hard pushed to ... rake up a dozen at the moment' (Gormley, 1982: 74). Similarly, Eric Heffer believed that June was too early, because 'we needed a little longer to regain our support', and as such, he 'felt that we could win in October, but had grave doubts about June' (Heffer, 1973: 168).

When Heffer's doubts about Labour's electoral prospects in June were subsequently vindicated, he claimed that (election night) conversations with members of his constituency [Liverpool Walton] Labour Party convinced him that 'one of the factors contributing to our defeat ... had been the attitude adopted by the Labour Government to industrial relations issues. In particular, the Prices and Incomes Policy, and In Place of Strife, came under heavy criticism' (Heffer, 1973: 169). The erstwhile Chancellor, Roy Jenkins, meanwhile, candidly conceded that '[i]t was broadly my policies on which Wilson had chosen to fight, and on which we had lost' (Jenkins, 1991: 303).

Of course, it was not necessarily an either/or issue: it is perfectly plausible to assume that some erstwhile or potential Labour voters declined to vote for the Party due to disappointment at the failure to enact industrial relations legislation, while others withheld their votes because of disapproval that the Government had devoted so much time and energy to attempting to place statutory obligations and restrictions on trade union activities. If this was the case, then the issue might have cost Labour votes from supporters and opponents of In Place of Strife alike.

However, attributing blame for Labour's defeat to the Government's troubles over industrial relations legislation is over-simplistic, for two reasons. First, hardly any political phenomenon can be adequately or accurately explained by a mono-causal account which attributes an occurrence or event to just one factor. Of course, a particular factor or event might be highly influential, and indeed, be the most important variable, but even when this is the case, other factors will have contributed to the significance of the 'key' factor, and thereby contributed towards, or enhanced, its impact. As such, rather than identify a single, causal, factor when explaining a political occurrence, it is essential to adopt a somewhat broader approach, or dig a little deeper, in order to examine the event more holistically.

In the case of Labour's 1970 election defeat, this means looking at the Party's overall record in government, the problems it encountered and its policy responses, of which In Place of Strife was just one - albeit obviously a significant one. To express it another way, Labour's electoral woes did not begin in the first half of 1969, when the battle over In Place of Strife was being waged, but much earlier, almost immediately after the 
Party's re-election in March 1966. The usual honeymoon period which governments often enjoy in the first few months after a general election victory was denied to the re-elected Labour Government, which faced serious economic problems from the outset. Indeed, some of these were indirectly exacerbated by its 1966 election victory, because Labour's re-election with a comfortable ninety-seven-seat Parliamentary majority caused consternation among senior industrialists and financiers that the Government might now feel sufficiently strengthened and emboldened to pursue a programme of radical economic and social reform and wealth redistribution, and inter alia significantly increase public expenditure.

Thereafter, the Labour Government struggled to win the confidence of the business community, as Ministers struggled to tackle a plethora of economic and industrial problems. Indeed, even though the Government responded by pursuing the traditional policies of deflation, entailing curbs on public expenditure and wage restraint via incomes policies, coupled with increased prescription charges in the NHS and postponing the planned raising of the school leaving age (from 15 years of age to 16), it continued to face scepticism from senior industrialists and investors about the Party's economic competence and probity. As noted in a mid-1960s editorial in The Economist, titled 'Labour men, Tory measures', 'when orthodox financial policies are pursued by a left-wing government, they do not attract the same return in financial confidence as exactly the same policies pursued by the Tories' (The Economist, 1965: 416). Yet whilst the Labour Government's deflationary policies failed to foster confidence among the business community, they did seemingly alienate some of Labour's working class and trade union supporters.

The second reason why it is over-simplistic to attribute Labour's 1970 electoral defeat to In Place of Strife is that, as noted above, during May and early June 1970 Labour enjoyed comfortable leads over the Conservatives in opinion polls, and performed well in local government elections. This strongly suggested that the Party's relatively recent problems over industrial relations had not prompted a significant desertion of former supporters, otherwise Labour would have trailed the Conservatives in the polls consistently throughout the campaign. As it was, Labour's support dissipated right at the very end of the campaign, during the last couple of days.

This last point strongly implies that the late collapse of Labour's support was largely prompted by unfavourable economic data published a couple of days before the election, which then prompted last-minute doubts about the Party's credibility and competence vis-à-vis its future stewardship of the British economy. For example, official statistics published on the Monday before the (Thursday) election revealed that Britain's trade/balance of payments deficit had increased in May, while polling day itself was accompanied by the publication of figures showing an increase in 
unemployment. Such data probably persuaded some voters that the apparent economic recovery which had occurred during the previous twelve months or so was rather more ephemeral or fragile than had been assumed. According to Shirley Williams, for example, '[t]he single most important factor reversing the public's favourable view of the government was ... the publication three days before election day of trade figures' which fuelled concerns that 'the government was not out of the woods as far as the economy was concerned' (Williams, 2009: 208).

Of course, if one particular set of economic data had such a major and damaging impact on Labour's electoral support in the last forty-eight hours or so of the campaign, then its apparent recovery in the opinion polls must have been fragile anyway. In fact, Williams herself notes that '[o]ne month's trade figures would not have so radically altered the course of the election had there not been a deep-seated unease about the administration's economic and industrial management' (Williams, 2009: 208-9). Or as Ponting averred, 'taken in isolation at a critical time', such figures seemed to vindicate Conservative claims that 'the economy was still weak and fragile' (Ponting, 1990: 388).

Moreover, an in-depth study of the 1970 general election suggested that there were already early indications that the British electorate, which had hitherto been notable for its high degree of party loyalty via class and partisan alignment, was starting to become more volatile, and thus somewhat less inclined to vote consistently for the same party at every general election. In this respect, dealignment had three consequences for general elections and voting behaviour, namely a greater willingness by voters to switch their support to another party, a higher propensity to abstain from voting and, as a consequence of the latter, a decline in electoral turnout.

Certainly, some of the data for the 1970 general election suggested that, instead of Labour suffering millions of the Party's erstwhile supporters switching to the Conservatives, a much more significant factor in its defeat was abstention by many disgruntled Labour supporters. As one eminent political scientist suggested at the time, '[t]he absolute fall in the Labour vote, by more than three-quarters of a million, is best interpreted as a positive decision by Labour voters to abstain' (Rose, 1970: 31; see also Panitch, 1976: 221).

That Labour was strongly affected by abstentions among its former supporters was acknowledged by some of the Party's MPs. Ian Mikardo, for example, reported that in his Poplar [East London] constituency:

[w] hat I heard on the doorsteps was not that a lot of people who had voted Labour in 1966 were going to vote Tory or Liberal in 1970, but that a lot of people who had voted Labour in 1966 were, in 1970, not going to vote at all. 
After the election, Mikardo somehow succeeded in locating 116 of these abstainers, and asked them what had prompted their decision not to vote. The standard response was that 'they couldn't see much, if any, difference between what the Labour Government had done in the last four years, and what a Conservative Government would have done' (Mikardo, 1988: 181, 182).

The impact of late abstentions on Labour's electoral support was also observed by the Foreign Secretary, Michael Stewart, in his Fulham constituency. He recalled that '[i]t was not till $6.00 \mathrm{pm}$ on polling day ... that I saw what was happening; that is when one can see whether Labour voters are coming out in sufficient numbers. They were not' (Stewart, 1980: 254). Likewise, in his Coventry East seat, Richard Crossman recognised that, by the evening of polling day, it was obvious that something was going very badly wrong. The poll [turnout] was only just over 50, 52, 55 per cent, even in our safest, biggest wards, and by 9 o'clock, it was only 60 per cent'. Upon reflection, Crossman concluded that, although some erstwhile Labour voters might have switched to the Conservative Party, most of the electoral swing to the Conservatives 'was the result of Labour abstentions' (Crossman, 1977: 949, diary entry for 19 June 1970).

What compounded the deleterious impact of abstentions on Labour's electoral performance in June 1970 was that the Conservative Party had benefited from an increase in turnout (compared to 1966) among its supporters. In several seats, the increase in the number of Conservative votes was much greater than the decline in Labour's vote, thereby reaffirming Crossman's contention that Labour suffered primarily from abstentions, rather than former supporters switching to the Conservative Party en masse. For example, in the Merseyside constituency of Bebington, Labour polled just ten votes fewer than in 1966, whereas the Conservatives won an additional 3,000+ votes in 1970. Meanwhile, in Bedfordshire South, the Labour Party vote fell by 1,442 in 1970 (compared to 1966), while the Conservative vote increased by 7,776 .

Furthermore, in a few constituencies Labour actually won more votes than in 1966, but still lost because the Conservatives won an even larger increase. This was certainly the case in the Derbyshire constituency of High Peak, where the 1970 election saw Labour attract an extra 1000+ votes compared to 1966 , whereas the Conservatives vote increased by $3,000+$. In such constituencies, the Conservatives seemed to have benefited from a significant increase in turnout among their own supporters compared to 1966.

One other voting variable which seems to have damaged Labour's performance in the 1970 election, while correspondingly benefiting the Conservatives, was the role of the Liberal Party and its candidates. In particular, there were some constituencies where the Liberals did not 
field a candidate in 1970, having previously done so in 1966. In many such constituencies, much of the Liberals' former support was transferred to the Conservatives in 1970, rather than to Labour. For example, having won 6,382 votes in Stretford in 1966, the Liberal Party did not field a candidate in 1970, whereupon the Conservatives won an additional 7,255 votes, while Labour's support fell by just 125 votes.

Conversely, there were some constituencies which the Liberals had not contested in 1966, but did contest in 1970, and in some of these, that Party's tally of votes was remarkably similar to the Labour Party's loss of votes compared to 1966. Indeed, in thirteen of the seats which the Conservatives won from Labour in 1970, the Liberal Party fielded a candidate having not done so in 1966. For example, in Brighton Kemptown, Labour's vote fell by 3,831 in 1970, while the Liberal candidate won 3,833 votes - just two more than Labour's loss. This enabled the Conservatives to win the seat by a margin of 3,103 votes, even though their candidate only won 103 votes more than in 1966. A similar scenario ensued in Stockport North, where Labour's 1970 vote was 4,330 lower than in 1966, whereas the Liberals won 4,022 votes. Again, the Liberals' intervention benefited the Conservatives, who won the seat from Labour by a margin of just 871 votes, having attracted only 130 votes more than in 1966.

This suggests that, alongside abstentions by some former Labour supporters who were disappointed with the record of the 1966-70 Labour Government, at least some of those who had voted for the Party in 1966 switched to the Liberals (rather than to the Conservatives) four years later. This, in turn, would have split the non-Conservative vote in some constituencies, and - owing to the operation of Britain's simple plurality (first-past-the-post) electoral system - this enabled the Conservative candidate to win the seat, irrespective of whether they had significantly increased the number of people voting for them.

Consequently, rather than treating In Place of Strife as if it was the key variable in explaining Labour's defeat in the 1970 election, the White Paper should be comprehended in the context of Labour's overall record in office, and the sundry economic problems the Government faced, coupled with its consequent policy responses (for a fuller account of why Labour lost the 1970 general election, see Dorey, 2013a).

Furthermore, it could be argued that the battle over In Place of Strife was, or subsequently became, symptomatic and symbolic of more significant and substantive dilemmas which face(d) Labour governments, and which periodically fuelled tensions between the Labour Party and the trade unions - the political and industrial wings of the organised labour movement in Britain. The economic and industrial problems affecting Britain in the 1960s, and the 1964-70 Labour Government's policy responses, 
brought, these dilemmas and tensions to the fore, but then, in turn, had fatal consequences for Labour's electoral support and performance.

\section{The 'national interest' and electoralism vs sectional interests}

One of the most obvious and general sources of tension between the Labour Party and the trade unions, which was particularly pronounced during the latter half of the 1960s, concerns the different perspectives and pressures faced by Labour Governments, which brought them into conflict with the trade unions. In fact, there are two broad aspects to this conflict of interests. The first is that, whereas the trade unions have just one socio-economic interest - albeit one which has been inextricably linked to the Party financially and organisationally - Labour has had to appeal to a much wider range of interests and sections of society in order to be electable and evince governmental competence, which has meant addressing two other crucial 'constituencies'.

The first of these is big business, financiers and industrialists, all of whom have feared the Party's professed Socialist principles and hostility to capitalism (such fears strongly imply that they took Labour's egalitarian rhetoric far too seriously or literally), and/or harboured grave doubts about Labour's economic competence, in terms of its ability to provide the economic conditions or circumstances in which capital accumulation, profitability and shareholder value could continually be increased. This has historically placed the Labour Party in an almost impossible situation, for the Party has simultaneously sought to pledge or deliver material and tangible improvements to workers and trade unions, while promising capital and 'the City' that it will pursue business-friendly policies which boost profitability and shareholder value. The latter will often entail convincing the business community that a Labour government will secure the compliance of the trade unions in not pursuing 'excessive' wage increases which would result in higher labour costs, and thus erode profit margins. In other words, the Labour Party has repeatedly been obliged to reassure big business and 'the City' that it will 'contain' or restrain the trade unions and hold down wages, while the Conservatives have never felt compelled to reassure the trade unions that a Conservative government will keep big business or employers 'under control' by curbing huge profits, or curtailing enormous salaries and bonuses in company boardrooms or 'the City'.

The second way in which the Labour Party has had to appeal far beyond the trade unions and their members in order to be elected (or merely viewed as electable - a credible government-in-waiting) is by rendering itself attractive to ordinary or middle-of-the-road voters, many of whom are not trade unionists, or working class. Indeed, particularly in recent 
decades, as the traditional working class has declined and trade union membership has plummeted, the Labour Party has been obliged to broaden its electoral appeal by seeking to attract support both from the growing middle class, and the increasing number of non-trade unionists; in effect, becoming a genuinely catch-all party, as exemplified by the post-1994 phenomenon of New Labour.

Certainly, much of the impetus for In Place of Strife and the ensuing Industrial Relations Bill was the perceived need to pacify the concerns of both the business and financial communities, and the wider electorate, about the industrial disruption and consequent economic damage attributed to unconstitutional and unofficial strikes. Yet seeking to assuage such concerns inevitably brought the Labour Government into conflict with the trade unions. However, the unions' hostility to In Place of Strife was exacerbated by the fact that this recourse to industrial relations legislation not only defied the main recommendations of the Donovan Report, but also followed several years of Ministerial efforts to curb wage increases, and inter alia inflation, via increasingly stringent incomes policies.

Of course, pay restraint had also owed much to the Labour Government's need to assuage the serious concerns of business elites and capital about Labour's stewardship of the British economy, but it also highlighted a further tension between a Labour Government's response to economic exigencies, namely incomes policies to restrain pay increases, and a fundamental principle of Britain's trade unions, namely the commitment to free collective bargaining to increase earnings.

\section{Incomes policies vs free collective bargaining}

Britain's trade unions have long been strongly committed to 'free collective bargaining', in which wage determination is, or should be, 'free' from political interference or State control. Even when Britain has had a Labour government, the trade unions have generally remained committed - at least in principle - to free collective bargaining, insisting that wages could only ever be planned and controlled by the State when capitalism had been superseded by Socialism, and the rest of the economy itself planned and placed under 'democratic' control. Until such time, in the words of Frank Cousins when addressing the TUC's 1956 conference (while he was leader of the TGWU, Britain's largest trade union at the time), in a period of freedom for all, we are part of the all'. Indeed, in 1966, Cousins resigned as a Cabinet Minister when the Labour Government adopted an incomes policy as an integral component of its economic and industrial strategy.

Trade unions also resented the manner in which incomes policies - even when adopted by Labour governments - reflected the premise that it 
was workers' wage increases which were the underlying cause of domestic inflation, rather than price increases intended to boost profits and shareholders' dividends (although companies often retorted that their price rises were often caused by the need to cover the higher labour costs accruing from wage increases). Certainly, the unions could argue that curbs were rarely imposed on high pay or bonuses in Britain's boardrooms or 'the City'; it was only workers' wages - not bosses' salaries - that were condemned as being excessive, economically damaging, greedy, inflationary and liable to increase unemployment through 'pricing people out of work'.

Although many trade union leaders initially acquiesced in the recourse of incomes policies, they did so for two main reasons: a) it was a Labour government adopting such a policy, rather than the Conservatives, so it was expected to be 'fairer' or more equitable; b) incomes polices were assumed to be a short-term emergency measure to tackle a particular economic crisis, after which there would be a return to free collective bargaining. However, as Labour governments sought to extend or renew each incomes policy on an annual basis, so trade union support diminished, thereby fuelling tensions between the political and industrial wings of organised labour, particularly as a new generation of more left-wing trade union leaders emerged in the 1960s, most notably Jack Jones and Hugh Scanlon: 'militant free collective bargainers' (Ackers, 2018: 272). As noted earlier, some critics suggested that the attempt by the 1966-70 Labour Government to hold down workers' wages via incomes policies - while also cutting public expenditure and the social wage - was a key reason (but certainly not the only one) for the Party's defeat in the 1970 general election.

Alongside the disjuncture between governmental incomes policies and the trade unions' commitment to free collective bargaining, the 1964-70 Labour Government's recourse to formal pay restraint encountered or exacerbated another practical problem, namely that of 'wage drift', for as we noted in chapter 1 , as pay increasingly became formally determined centrally at national level, and often between union leaders and government Ministers, there was a counter-trend whereby local-level, more informal, wage bargaining increased, and this often yielded wage increases which were higher than those officially agreed nationally. This, in turn, served to enhance the authority, loyalty and respect enjoyed, in the workplace, by local-level union officials and shop stewards, for these were visibly pursuing the material interests of their members, whereas the national union leadership seemed to have become out of touch, and appeared to be colluding with Ministers to hold down workers' wages via incomes policies.

Of course, it was this gulf which underpinned the 'two systems' (formal and informal) of industrial relations and collective bargaining, as noted by the Donovan Report, and which largely prompted Barbara Castle's 
proposed reform of industrial relations via In Place of Strife, although Ministers and officials harboured divergent views about whether this was intended to make incomes policies more viable and effective, or render them unnecessary, on the grounds that reform would yield more stable, orderly and 'responsible' collective bargaining.

Yet pay determination, be it free collective bargaining or incomes policy, encountered another problem derived from the structure of British trade unionism, namely the fact that Britain's unions have been organised primarily on occupational grounds and, in this regard, become an inadvertent or unintentional source of (working) class fragmentation, rather than the basis of workers' solidarity (Ackers, 2018: 272-73; see also Anderson, 1967). Although there has always been a left romanticism about the organised working class as a vehicle for consciousness-raising and Socialist transformation, this long-term vision has repeatedly conflicted with the essentially sectional and short-term interests of trade unions, which seek to improve the material conditions and wages of their members (based on occupation or industrial sector) within capitalism. Many trade unions have pledged their commitment to Socialism, but this has often been a rhetorical or vague future goal, and in the meantime they have, in effect, competed against each other to secure the best deal for their members, with little genuine regard for other workers and trade unionists.

In this particular regard, trade unions are themselves a paradoxical product of capitalism, simultaneously providing their members with some protection against the worst forms of exploitation and immiseration - or lobbying for such protection - but nonetheless internalising the functional logic of capitalist competition when seeking the 'best deal' for their members. Just as a company is not concerned with the material well-being or welfare of other companies against which it is competing, so Britain's trade unions have rarely evinced much concern for the fate of other unions and their members, even when denouncing the inequities and injustices of capitalism. This further exacerbated the problems encountered by Labour Governments in the 1960s and 1970s in persuading the trade unions collectively to adopt both more responsible industrial behaviour and a longer-term perspective in response to Britain's economic problems and governmental policies to tackle them.

\section{The longer-term consequences: from the 1969 White Paper to the 'winter of discontent'}

Having lost the 1970 general election, the Labour Party and the trade unions naturally sought to foster a rapprochement, to put the bitterness engendered by In Place of Strife behind them and thenceforth ensure that the political and industrial 'wings' of organised labour could work more 
harmoniously together next time there was a Labour government. Indeed, it was recognised that Labour's future electoral prospects would be greatly enhanced by being able to convince voters that it was the only party which could establish, and then sustain, a more constructive and fraternal long-term relationship with the trade unions. Yet in the context of these observations, this new rapprochement was almost inevitably doomed to fail, although it was initially facilitated by joint Labour-trade union hostility to the Conservative 'enemy', before fracturing when the next Labour government again fatally foundered, and thereupon proved unable to 'deliver', in the face of severe economic difficulties in the latter half of the decade.

\section{The Conservatives' 1971 Industrial Relations Act}

Initially, a closer relationship and relative unity between the Labour Party and the trade unions was facilitated by their combined opposition to the newly elected Heath Government's Industrial Relations Bill, which also sought to impose a series of statutory curbs and regulations on the trade unions, but which were rather more extensive than those proposed by In Place of Strife. However, the Conservatives' Industrial Relations Bill unwittingly enshrined sundry inconsistencies, some of which were highlighted by Conservative MPs during the legislation's Parliamentary debates and (committee stage) scrutiny.

One of these concerned the provisions for weakening the 'closed shop', a system of compulsory trade union membership under which obtaining or retaining a job was dependent on being, or immediately becoming, a member of a trade union; often a specific, designated, union. In attempting to weaken the closed shop, Conservative Ministers were immediately confronted with a problem which had perennially faced their Party in denouncing such compulsion, namely the tension between promoting individual liberty and maintaining industrial order (Dorey, 2009a). On one hand, many Conservatives instinctively or ideologically condemned the closed shop for constituting a form of industrial conscription and trade union tyranny, because some workers were required to join a union against their wishes; indeed, they might have conscientious objections to belonging to a trade union. Yet failure to be(come) a union member could result in loss of employment, or failure to be appointed in the first place, even though they might be ideally qualified and/or perform extremely well at the job interview.

On the other hand, some Conservative MPs (particularly those originating from industrial or managerial backgrounds) recognised that maximum trade union membership could facilitate greater industrial order, because if all workers in a company or industry belonged to a specific trade union there would be far fewer demarcation and/or inter-union 
disputes. Moreover, management would benefit by only needing to negotiate with one set of trade union leaders or officials during pay bargaining, or discussions over other terms and conditions of employment. Conversely, for the Conservatives to encourage non-union membership, or permit workers to join any trade union they wished (in the guise of freedom of choice), the result was likely to be the fragmentation of trade unionism. Not only would this seriously undermine the Government's over-riding objective of imbuing industrial relations with greater order and stability, it would also make the role of management and employers much more onerous.

Some Conservative MPs also pointed out that maximising union membership would ensure that 'moderates' were trade unionists, and therefore more able to counter the influence of the left, whereas if union membership was solely a matter of individual choice then many 'moderates' would feel less inclination or motivation to join, and thereby inadvertently enable the (more active and organised) left to dominate the unions (Dorey, 2009a: 227-8). In the face of such arguments, the Industrial Relations Bill's provisions to outlaw the closed shop were amended, so that maximum union membership was to be encouraged, but with statutory safeguards for workers who harboured strong moral objections to being, or becoming, trade union members.

The official trade union response to the Industrial Relations Bill was one of 'passive non-co-operation', although this did not preclude extraParliamentary action in the form of demonstrations, marches and rallies seeking to 'kill the Bill' whilst it was still wending its way through Parliament. Once the Bill had become law, most trade unions simply refused en masse to register with the new Registrar of Trade Unions and Employers Associations, as they were required to do if they were to retain their legal immunities.

However, it was the judiciary - not normally known for its comradely sympathy towards the trade unions - which grievously undermined the Industrial Relations Act, quite unwittingly. In one instance, dock-workers who were members of the TGWU refused to handle the containers of Heaton's, a firm on Merseyside, because it was employing non-dock labour at its terminals. The TGWU defied an instruction by the National Industrial Relations Court (NIRC) to order the dockers to stop this refusal to deal with Heaton's containers, whereupon it was fined $£ 5,000$ for contempt of court, ${ }^{3}$ this subsequently being increased to $£ 50,000$ when the 'boycott' continued. ${ }^{4}$

When the TGWU then took the case to the Appeal Court, claiming that it could not be held responsible for the actions of individual members who acted without the union's authorisation and who rejected the union's request to desist, its appeal was upheld. This favourable judicial decision was subsequently overturned by the 'Law Lords' (then Britain's highest judicial body and court of final appeal), but by this stage some of the 
inconsistencies in the Industrial Relations Act, in this case, the tension between the freedom of individual trade union members and the authority of their leaders, had become fully apparent. As with the closed shop, the twin Conservative tenets of liberty and order could not always be easily reconciled.

What ultimately proved fatal to the Industrial Relations Act was another bitter industrial dispute involving dock-workers, which resulted in five shop stewards being sent to prison after defying an order by the NIRC to stop picketing a firm employing non-dock labour. Their imprisonment provoked a national dock strike, accompanied by sympathy or solidarity action from other workers and trade unions. However, the Law Lords' verdict in the earlier Heaton's case, in which it had judged that the trade unions, not individual members, were ultimately legally responsible for industrial action, effectively absolved the 'Pentonville Five' dockers from legal liability, thereby ensuring their immediate acquittal and release from prison in August 1972.

The manner in which these judicial decisions highlighted inherent flaws and inconsistencies in the Industrial Relations Act, coupled with the willingness of trade unions to mobilise in support of fellow trade unionists who were prosecuted (and sometimes imprisoned) for defying the Act, effectively destroyed the credibility and effectiveness of the legislation. Although the Conservative Prime Minister, Edward Heath, refused to repeal the Act, it was tacitly acknowledged that it would no longer be invoked and instead, a new partnership with the trade unions sought instead as the primary means of improving industrial relations (on the failure of the Act, see Campbell, 1993: chapter 24; Moran, 1977: chapters 8 and 9; Taylor, 1993: 186-202; Taylor, 1996: 169-76; Whitehead, 1985: chapter 4; Williamson, 2015: 174-7).

Had the Conservative Government's 1971 Industrial Relations Act proved successful, it would almost certainly have proved problematic for Labour, because a pledge by the latter to repeal the Act would inevitably have been portrayed, by the Conservatives (and their many allies in the press) as both a recipe for returning to industrial chaos and trade union militancy, and evidence that Labour placed the interests of its trade union 'pay-masters' above those of the nation itself. However, the de facto defeat of the Industrial Relations Act, within a year of being placed on the statute book, meant that Labour's subsequent pledge to repeal it was much less contentious than it would otherwise have been.

\section{The Labour-trade union 'social contract'}

Meanwhile, the pursuit of a rapprochement between the Labour Party and the trade unions yielded the 1972 'social contract', which decreed 
that if the trade unions exercised voluntary wage restraint, and took into account the overall state of the economy when submitting pay claims, the next Labour government would enact a tranche of policies to improve the social wage, such as increasing old-age pensions and introducing subsidies for transport fares, rents and some food items. The 'social contract' also entailed a commitment by the Labour Party to repeal the Industrial Relations Act, strengthen employment protection and workers' rights, and introduce industrial democracy (Coates, 1980: 82-3; Taylor, 1978; Taylor, 1993: chapter 7; Trades Union Congress, 1973a; Trades Union Congress, 1973b; Whitehead, 1985: chapter 6).

The Labour Party's leadership clearly hoped that improvements in the social wage would deter the trade unions from pursuing significant increases in 'real' wages, and thereby simultaneously facilitate sustained economic growth and full employment without fuelling inflation. Indeed, the success or failure of the 'social contract' would depend upon this, as was made clear in Labour's October 1974 election manifesto, which declared that:

[a]t the heart of this manifesto and our programme to save the nation lies the Social Contract between the Labour Government and the trade unions ... The Social Contract is no mere paper agreement approved by politicians and trade unions. It is not concerned solely or even primarily with wages. It covers the whole range of national policies. It is the agreed basis upon which the Labour Party and the trade unions define their common purpose ... the firm and detailed commitments which will be fulfilled in the field of social policy, in the fairer sharing of the nation's wealth, in the determination to restore and sustain full employment. The unions in response confirm how they will seek to exercise the newly restored right of free collective bargaining. Naturally the trade unions see their clearest loyalty to their own members. But the Social Contract is their free acknowledgment that they have other loyalties - to the members of other unions too, to pensioners, to the lower-paid, to invalids, and to the community as a whole. (Labour Party, 1974: 5)

However, when Labour was returned to Office in 1974 - initially as a minority government after an inconclusive February election and Heath's failure to secure Liberal Party support for a coalition government (Dorey, 2008-09), and then with a wafer-thin Parliamentary majority in October 1974 - the new Cabinet was immediately beset by serious economic problems. The most notable of these was a rate of inflation which peaked at 25 per cent in 1975, largely due to the knock-on effects of a 400 per cent increase in international crude oil prices during 1973, which filtered through the economy and impacted on prices during the next eighteen months or so. Although Heath's Conservative Government had been in office at the time of this increase, the enormous surge in inflation coincided with Labour's first full year in government, and thus significantly 
contributed to the subsequent doubts about the Party's economic competence and credibility.

Just as in 2008, when the global financial crash occurred, followed by a decade of austerity policies in Britain entailing major cuts to public expenditure and welfare, and pay freezes for millions of workers, Labour were given the blame for a major economic crisis which originated overseas but was then attributed to Labour's own fiscal policies and 'excessive' spending. In short, both during the late 1970s and late 2000s, Labour governments incurred the opprobrium for problems emanating from the periodic crises and inherent contradictions of capitalism, 'market' neoliberalism and globalisation, yet in both instances the Conservatives readily persuaded much of the electorate that these were crises of Socialism or social democracy.

The circumstances facing Labour when it entered office in 1974, and many of the new Government's subsequent policy responses, bore several similarities to those which had pertained following Labour's 1966 election victory. History did indeed repeat itself a decade later, albeit as further tragedy, not farce. Having promised the trade unions higher public expenditure and improvements in the social wage in return for voluntary pay restraint - 'responsible' collective bargaining - the post-1974 Labour Government, just like its predecessor a decade earlier, immediately embarked upon a series of increasingly stringent incomes policies to curb pay increases (in order to both curb inflation and win the confidence of industrialists, investors and financiers), coupled with cuts in public expenditure (which were deepened under the conditions imposed by the International Monetary Fund when it granted the Government an emergency loan in 1976) and the social wage (see Dorey, 2001: chapter 6, for an examination of the 1974-9 Labour Government's incomes policies and the trade unions' response).

For the first two years, the TUC again grudgingly accepted the Labour Government's recourse to formal incomes policies, partly through cognizance of the seriousness of the economic situation, and partly because the trade unions were convinced that these were temporary measures ahead of a return to free (but responsible) collective bargaining once the crises had abated. Yet economic recovery proved much more elusive than had been envisaged, so that by late 1976 Ministers were faced with a serious dilemma; the economic circumstances which would make the trade unions hostile to continued pay restraint - high inflation (which thus eroded workers' living standards), rising unemployment, cuts in public expenditure and the social wage - also made incomes policy more necessary, at least from the Government's perspective. Indeed, as in the latter half of the 1960s, some Ministers who had initially viewed incomes policies as a temporary, short-term, response to dire economic 
circumstances, subsequently saw them as a permanent tool of economic management and counter-inflation strategy (Callaghan, 1987: 521).

\section{Towards the 'winter of discontent' and subsequent electoral defeat}

Thus it was that when the Labour Government sought to impose a fourth successive year of pay restraint in 1978-9, with wage increases to be limited to 5 per cent (while the inflation rate was 8 per cent), many trade unions effectively rebelled. In some cases, it was employers who proved willing to exceed the Government's 5 per cent pay limit, either to avert strike action over pay claims or to improve their recruitment of workers to fill key vacancies by offering higher wages, regardless of the levels or limits decreed by Ministers. For example, in November 1978 a nine-week strike by Ford car workers was called off when the union accepted the management's offer of a 17 per cent pay rise. At about the same time, road haulage drivers accepted a 21 per cent pay increase after striking for three weeks, while a threatened strike by petrol tanker drivers, in pursuit of a 25 per cent pay rise, was only averted when the employers offered a 20 per cent increase, which was accepted. Each time a trade union or category of workers secured a pay rise much higher than the 5 per cent decreed by the Government, other trade unions and workers felt emboldened or compelled to follow suit, while claiming 'comparability'.

Consequently, early 1979 heralded several strikes in support of 'large' pay claims, the most serious of which involved low-paid workers, often employed in the public sector. By their very nature, these strikes caused widespread disruption and inconvenience, and greatly exacerbated public hostility towards 'selfish' trade unions, because many of those most seriously affected by these stoppages were not capitalist employers or 'greedy bosses' but ordinary citizens, and sometimes people who were particularly vulnerable, such as those who had recently experienced the death of a spouse or close family member, but who had to delay the funeral owing to a strike by local council grave-diggers, triggering press headlines claiming that 'They won't even let us bury our dead'.

Other public sector strikes which caused widespread disruption and inconvenience during early 1979 included one by school caretakers, which led to schools being closed, and some parents thus having to take time off work to look after their children (particularly in the absence of a child-minder, which they might have been unable to afford). Another major strike involved refuse collectors (or 'dustmen', as they were widely known), which meant that household and commercial waste was not collected for several weeks: in an era long before recycling and separate containers for different types of waste, bin-bags and dustbins containing 
rotting food posed a considerable health risk, as well as attracting rats. This strike also provided pro-Conservative newspapers with ample opportunities to publish damning pictures of bags of festering, stinking rubbish piled high in Britain's streets.

This spate of strikes became known as 'the winter of discontent', and placed the Labour Government in a no-win situation. If it stood firm and refused to yield to 'excessive' pay claims, it was liable to be condemned by the public and the press for being complacent, incompetent or outof-touch, and for allowing the widespread disruption of public services to continue unchallenged. Yet if it sought to end the strikes by acceding to the pay claims, it would doubtless have been accused of being weak, and surrendering to trade union militancy. In attempting to extricate itself from this quandary, the Cabinet hurriedly established a Commission on Pay Comparability, chaired by Professor Hugh Clegg, which it was envisaged would provide the Government with a pretext for awarding pay rises above 5 per cent.

In the meantime, Ministers also desperately sought to reach a new concordat with the TUC, which 'at least give us a piece of paper on which to fight an election' (Barnett, 1982: 176). What transpired was a 'joint statement' committing Labour and the trade unions to reduce inflation to 5 per cent within three years, with an annual 'economic assessment' being conducted to gauge what level of pay increases was affordable, and commensurate with this inflation target (Donoughue, 1987: 177-8). Under pressure from Ministers, the TUC also issued guidance to affiliated unions concerning the conduct of future strikes, most notably urging greater responsibility when engaging in such activities as picketing or pursuing 'secondary' industrial action; for example, the targeting of other firms which were not directly involved in a dispute, but which were supplying materials to the firm which was at the heart or source of the strike.

These responses were too little, too late. Many trade unionists had become deeply disillusioned with incomes policies, and inter alia the Labour Government, not merely because of their a priori commitment to free collective bargaining, but because of the impact on wages. In fact, by early 1979 workers' opposition to pay restraint emanated from two distinct sources. On one hand, low-paid workers understandably viewed repeated wage restraint as a major reason for their poverty wages and material hardships, even though Labour's incomes policies had sometimes permitted somewhat higher increases for the lowest-paid. On the other hand, skilled workers, on higher wages, increasingly resented the erosion of 'differentials' which accrued from incomes policies that were slightly more generous to those on the lowest wages. In effect, Britain's 'labour aristocracy' baulked at incomes policies which were perceived to be too egalitarian, and 'levelled down' higher-paid workers. Consequently, in the May 1979 general election, the largest swing to the Conservatives (of 
11 per cent) was among skilled workers (the C2s as they have often been referred to subsequently), who were evidently attracted by the Conservatives' pledge of a return to free collective bargaining, coupled with a professed commitment to restoring pay differentials linked to skills (Kellner, 2015: 229).

More generally, the 'winter of discontent' had appalled and alienated many voters, and caused considerable resentment of the trade unions, which in turn damaged Labour's credibility and popularity. Having previously been widely viewed as organisations which fought for fairness, justice and the underdog, many people now viewed the trade unions as selfish tyrants and swaggering bullies who were devoid of decency and compassion, rather than the 'wicked capitalists' or 'greedy bosses' routinely denounced by the left. This public revulsion manifested itself in the strong leads enjoyed by the Conservatives in opinion polls during early 1979: an Ipsos MORI/Daily Express poll in early February, for example, reported a 55 per cent-36 per cent lead over Labour, while 51 per cent of respondents considered strikes/trade unions to be the most important issue facing Britain (in contrast, only 1 per cent cited education, and 2 per cent cited the NHS). The poll also revealed that 89 per cent of respondents believed both that trade unions should be required to ballot their members prior to a strike, and that 'secondary picketing' should be banned.

Senior Labour Ministers were virtually resigned to electoral defeat in the imminent general election. The previous August, James Callaghan had contemplated calling an autumn 1978 general election, which is what many of his Ministerial colleagues and advisers were advocating. However, the ultra-cautious Callaghan decided that the opinion polls were too close, with Labour and the Conservatives virtually neck-and-neck; it was too risky. ${ }^{5}$ He therefore resolved to defer the election until 1979, hoping that the economic situation would steadily improve during the winter months, in tandem with Labour's poll ratings, sufficient to secure electoral victory in a spring election (Dorey, 2016a). ${ }^{6}$

In so doing, Callaghan also assumed that, whilst the trade unions were unhappy at the 5 per cent pay limit, they would refrain from widespread defiance and industrial action during the winter of 1978-9, lest they jeopardise Labour's prospects of re-election in the Spring. ${ }^{7}$ This, of course, proved to be a deeply erroneous assumption, one which a Cabinet colleague attributed to 'a tragic over-estimation of his own influence with the trade union leaders, and of their influence over their members' (Williams, 2009: 248). The clear implication was that Callaghan would be able to call in a favour from the trade unions in return for having opposed In Place of Strife a decade earlier. It proved to be a fatal miscalculation, for as Callaghan himself subsequently noted, '[t]he serious and widespread industrial dislocation caused by the strikes of January 1979 ... sent the government's fortunes cascading downhill' (Callaghan, 1987: 540). His Chancellor, Denis 
Healey, was rather blunter, asserting that ' $\mathrm{t}$ ] he cowardice and irresponsibility of some union leaders ... at this time, guaranteed her [Margaret Thatcher's] election' (Healey, 1990: 462; see also Donoughue, 1987: 180, 187; Donoughue, 2008: 498-9).

However, as in 1970, some on Labour's left insisted that electoral defeat was primarily the fault of those Ministers who had refused to heed or understand the frustration of ordinary trade unionists in the context of repeated wage restraint and public expenditure cuts. Eric Heffer, for example, argued that 'the government was responsible for its own unpopularity, and certainly laid the basis for its defeat' by alienating its own working-class supporters. Indeed, Heffer singled out Healey for particular criticism, by denouncing the ex-Chancellor's 'colossal arrogance' in blaming workers and trade unions, rather than Healey's own economic policies. Heffer claimed that Healey had 'little real understanding of ordinary working people', and tartly suggested that '[p]erhaps if he had listened to rank-and-file workers, rather than those in the City ... things might have gone better' (Heffer, 1991: 167).

Meanwhile, on the day before the 1979 general election, Tony Benn (who had moved decisively to the left since the late 1960s, when he had supported In Place of Strife) complained that 'we've had a right-wing leader, a right-wing policy, a right-wing Cabinet, a right-wing manifesto and a right-wing campaign' (Benn, 1990: 493, diary entry for 2 May 1979). Benn also reported a conversation he had had, a few days after the election, with one of Labour's former whips, Joe Ashton, during which the latter asserted that 'incomes policy had been the cause of Labour's trouble' (Benn, 1990: 499, diary entry for 8 May 1979).

Regardless of who was to blame, the 'winter of discontent' effectively guaranteed the Conservative Party's victory in the May 1979 election whereupon Labour was consigned to impotent Opposition for the next eighteen years (on the 'discursive' and 'ideological' representations of the 'winter of discontent' by the Thatcherite right of the Conservative Party, see the discourse analysis of Hay, 1996; Hay 2010). Electoral victory also persuaded the Conservatives that there was now a strong appetite for trade union reform among a British public which was exasperated with strikes and the associated economic damage and social disruption - as were many trade union members.

As a biographer of Thatcher notes: 'Not only was Callaghan's credibility destroyed, but public anger at the unions' indiscipline silenced the objections of her Tory critics, and gave Mrs Thatcher's incoming Government the mandate to tackle the abuses of trade union power which she had lacked the previous autumn' (Campbell, 2000: 414-15). Or, as one of her senior Cabinet colleagues averred: 'It needed further hard experience, culminating in the Winter of Discontent ... before the British people were 
ready to give continuous backing to a Government for trade union reform' (Whitelaw, 1989: 75-6).

Furthermore, by this time the Conservative Party had spent its period in Opposition honing a new approach to industrial relations and trade union reform, one which aimed to achieve many of the objectives originally pursued by the Heath Government, but avoiding the 'big bang' approach symbolised by the all-encompassing 1971 Industrial Relations Act; it was widely acknowledged inside the Thatcher-led Conservative Party that the 1971 legislation had attempted too much, too soon, and had been overly legalistic. Thus did the 1974-9 Conservative Opposition devise a more strategic, longer-term, step-by-step, industrial relations policy to curb the trade unions irrevocably (Dorey, 2009b; Dorey, 2014; Dorey, 2016b), with breaches of the law cast as civil, not criminal, offences (thus avoiding trade unionists being sent to prison and becoming martyrs), a discourse of 'democratisation' deployed to render the reforms more popular to ordinary union members, and careful planning in advance of major industrial 'battles', which would be provoked only when the Government had amassed sufficient resources to ensure its victory: the 1984-5 miners' strike being the most obvious example (Dorey, 2013b).

For the Conservatives, the success of this legislative approach was greatly assisted and reinforced by wider economic and structural changes which occurred or accelerated during the 1980s and beyond, most notably de-industrialisation, globalisation, privatisation and the general shift towards a post-Fordist economy. All these trends had a deleterious impact on trade union membership, and further weakened the unions, in tandem with the Thatcher Government's legislation. Furthermore, as the unions became weaker, fewer workers deemed them worth joining, which obviously meant that the decline in their membership and diminution of their strength continued unabated.

There was no attempt or desire to reverse these trends during the thirteen years of New Labour government which began in 1997. On the contrary, aligning itself with big business, pursuing supply-side economics and promoting 'labour market flexibility' were key characteristics of New Labour. In stark contrast, the trade unions were to be kept at arm's length, and in a clearly subordinate position. There was to be no return to beer and sandwiches' at 10, Downing Street, nor late nights sipping brandy with trade union leaders while brokering deals.

\section{Notes}

1 NA CAB 128/45, CC (70), 23rd Conclusions, 7 May 1970.

2 NA CAB 128/45, CC (70), 23rd Conclusions, 7 May 1970. 
212 Comrades in conflict

3 About $£ 73,500$ in 2018.

4. About $£ 735,000$ in 2018.

5 Callaghan Papers, Box 113, Hand-written note, 23 August 1978.

6 NA PREM 16/1621, Kenneth Stowe [Callaghan's PPS], 'Note for the Record', 6 September 1978.

7 NA PREM 16/1667, Prime Minister's Notes, undated but circa September 1978. 